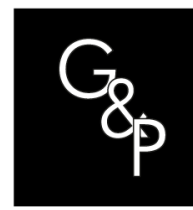

\title{
The use of system dynamics on urban solid waste management: a literature analysis
}

\author{
Aplicação da dinâmica de sistemas na gestão de resíduos sólidos \\ urbanos: uma análise das publicações
}

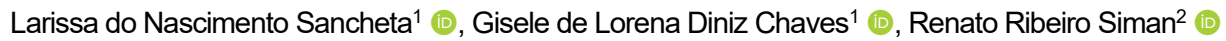 \\ ${ }^{1}$ Universidade Federal do Espírito Santo - UFES, Departamento de Engenharias e Tecnologia, São Mateus, ES, Brasil. \\ E-mail: larissa.sancheta@gmail.com, gisele.chaves@ufes.br \\ ${ }^{2}$ Universidade Federal do Espírito Santo - UFES, Departamento de Engenharia Ambiental, Vitória, ES, Brasil. E-mail: \\ renato.siman@ufes.br
}

How to cite: Sancheta, L. N., Chaves, G. L. D., \& Siman, R. R. (2021). The use of system dynamics on urban solid waste management: a literature analysis. Gestão \& Produção, 28(3), e5336.

https://doi.org/101590/1806-9649-2021v28e5336

\begin{abstract}
Urban solid waste management is a complex system due to the many variables that compose it, which makes it difficult for managers to make decisions. Among the decision-making tools is system dynamics. To identify the gaps between the literature and the studies about urban solid waste management by using system dynamics method, a survey of published papers on the subject was made, which were later analyzed using some defined criteria, such as the level of the study, the software used for modeling, the variables included in the model, among others. The research identified that, among the stages of solid waste management, the collection process is still little incorporated in the models, being mentioned in only nine studies analyzed. Besides, the environmental, financial and institutional requirements were not adequately explored in the models. Future research should endeavor to include these elements in the models, which will allow the proposed system to be approximated to the complex reality of solid waste management.
\end{abstract}

Keywords: Waste system; System dynamics; Bibliographic review.

Resumo: A gestão de resíduos sólidos urbanos é um sistema complexo em termos das inúmeras variáveis que o compõem, o que dificulta a tomada de decisão por gestores. Dentre as ferramentas utilizadas para o auxílio na tomada de decisão nestes sistemas está a dinâmica de sistemas. Visando identificar os gaps entre a literatura e os estudos já realizados acerca de gestão de resíduos sólidos urbanos a partir do método de dinâmica de sistemas, fez-se um levantamento de pesquisas já publicadas sobre o assunto que, posteriormente, foram analisadas a partir de alguns critérios definidos, tais como nível da aplicação do estudo, software utilizado para a modelagem, variáveis utilizadas no modelo, entre outros. A pesquisa identificou que, entre as etapas de gestão de resíduos sólidos, o processo de coleta ainda é pouco abordado nas modelagens analisadas, sendo citado em apenas nove estudos analisados. Além disso, os quesitos ambiental, financeiro e institucional não foram adequadamente explorados nos modelos. Pesquisas futuras devem se esforçar em incluir estes elementos nos modelos, o que permitirá a aproximação do sistema proposto à complexa realidade da gestão dos resíduos sólidos.

Palavras-chave: Resíduos sólidos urbanos; Dinâmica de sistemas; Revisão literatura.

Received Feb. 4, 2019 - Accepted Sep. 16, 2019

Financial support: None.

This is an Open Access article distributed under the terms of the Creative Commons Attribution License, which permits

unrestricted use, distribution, and reproduction in any medium, provided the original work is properly cited. 


\section{Introduction}

Globalization has provided new life perspectives and triggered behavioral changes due to the development achieved (Rosa \& Andrade, 2016). Among the negative aspects of these changes, there is an increase in the generation of solid waste and its inefficient management, which results in large volumes of waste disposed inadequately, especially in developing countries. Among the types of solid waste, Urban Solid Waste (USW) is generated in large volumes. In 2018, 79 million tons of MSW were generated in Brazil, which is about $1 \%$ higher than in 2017 (ABRELPE, 2018).

Solid waste management aims to minimize the environmental impact and include activities such as reduction, reuse, collection, sorting, recycling, transportation, treatment and final disposal of waste (Pisani et al., 2018). A viable alternative for dealing with complex systems, which includes solid waste management planning, is the use of quantitative techniques. These tools enable the representation of reality to study their behavior and make decisions based on the conclusions obtained (Simonetto \& Löbler, 2014).

Among the quantitative techniques, the System Dynamics (SD) method is used to describe, model, simulate and analyze dynamically complex problems and / or systems in terms of processes, information, organizational limits and strategies (Pruyt, 2013). The simulation of different scenarios by the DS method allows users to accelerate the collective learning about possible behaviors and impacts of complex systems; model and test policy and program design options; analyze and improve business processes; design and test new strategies that can conduct to better results; and lead to realistic decisions and more likely to achieve your goals (Healthy London, 2018). Therefore, this article aims to analyze the worldwide scientific production about DS modeling in the scope of MSW management. From the survey carried out in the literature demonstrated in Section 2 of this article, it was possible to define the criteria for analyzing published research.

\section{Brief theoretical review}

The legislation establishing the Brazilian Solid Waste Policy defines Urban Solid Waste (USW) as that coming from households and urban cleaning (Brasil, 2010). USWs make up a significant portion of solid waste and can be harmful to the environment and health if disposed inappropriately. Its management is necessary to guarantee environmental quality (Pisani et al., 2018).

Solid waste management includes the stages of segregation, collection, transport, treatment and final disposal (Satori et al., 2018). However, its proper implementation is not simple, especially in developing countries, which deal with a rapid increase in the generation of their USW (Wilson et al, 2012). Guerrero et al. (2013) raised the main factors that influence the performance of waste management systems in developing countries. The grouped data resulted in eleven groups: (i) Generation and separation; (ii) Collection, transfer and transportation; (iii) Treatment; (iv) Disposal; (v) Recycling; (vi) Technician; (vii) Environment; (viii) Finance / Economy; (ix) Sociocultural; (x) Institutional / Organizational; (xi) Political / Legal.

These indicate the many variables that influence the management of USW and, therefore, several authors point out that solid waste management as a complex system (Abeliotis et al., 2009; Kollikkathara et al., 2010; Ojoawo et al., 2012; Al-Khatib et al., 2015; Giannis et al., 2016). SD method helps to conceptualize and rationally analyze the structure, interactions and behavior of complex systems and subsystems to explore, assess and predict their impacts in an integrated manner (Kollikkathara et al., 2010). It is a methodology based on feedback systems, derived from the control theory, which can easily deal with nonlinear structures and 
time delay and multi-loop structures (Bala et al., 2017). It applies to any systems characterized by interdependence, mutual interaction, information feedback and circular causality with temporal dynamics (System Dynamics Society, 2018).

Popli et al. (2017) conducted a survey of studies on solid waste management using the SD method. The research concluded that this method is ideal for finding quantitative and qualitative relationships between the different variables of waste management to face environmental, social, technological and economic problems. To understand the components of the proposed models, an analysis of the literature was carried out, based on criteria defined according to the procedures presented below.

\section{Methodology}

The steps followed for the development of this study are shown in Figure 1.

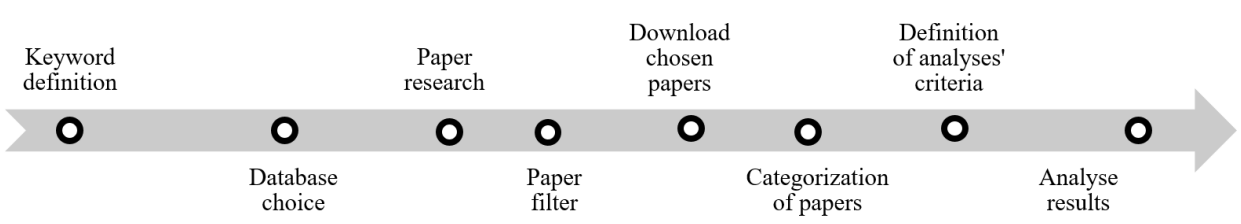

Figure 1. Research steps.

The theme of this research is the modeling of solid urban waste management using the DS method. The main words related to the subject were identified, namely: "resíduos sólidos urbanos", "dinâmica de sistemas", "municipal solid waste", "system dynamics", "urban solid waste", "urban waste management", "urban solid waste management", "municipal waste management", "glass waste", "metal waste", "paper waste" and "plastic waste".

The search for articles used two platforms: Web of Science and Google Scholar. The Web of Science platform connects publications and researchers through citations and controlled indexing in curated databases that cover all disciplines (Clarivate, 2018). Its choice was due to its relevance since its collection covers more than 33000 journals and makes it possible to search for recognized authors in the area of interest, in addition to being freely accessible to public Brazilian research institutions (Motta \& Quintella, 2012). In this case, only the combinations of keywords in English were used.

Google Scholar is a Google search tool that makes it possible to search for papers, theses, books, abstracts and opinions from courts, academic publishers, professional societies, online repositories, universities, and other websites. Among its features, there is the creation of a public author profile and the monitoring of citations of its publications (Google, 2018). It allows a broader range of research, making it possible to search not only journal articles, but also papers presented at congresses and undergraduate, master or doctoral theses. The use of both platforms allows a more complete analysis. The search in the Google Scholar database took place during the months of April and May 2018, in any language and at any time, including patents and citations. The search on the Web of Science took place in September 2018. The search used the Boolean expression 'AND', which allows the combination of two or more words.

Some points must be considered regarding the platforms used. The first refers to the inconsistency between the approximation of results that the Google Scholar platform informs and the number of results provided. When searching for "municipal solid waste" AND "system dynamics", for example, the Google Scholar platform reported an error in the system starting on page 99, so that 1230 results were not shown. 
From the preliminary analysis of the title, keywords and abstract, papers were selected according to the scope of the project. After this first filter, 166 articles were obtained by Google Scholar and 21 articles by Web of Science. After removing the repeated documents, the sample resulted in 72 studies. When starting to read the publications, he came across articles that did not fit the purposes of this study (did not present the SD model, for example) and, therefore, were excluded. The bibliographic portfolio evaluated contains 67 publications, of which approximately $64 \%$ refer to journal articles, $24 \%$ to papers presented at congresses and $12 \%$ to undergraduate, master and doctoral theses.

In the next stage, the publications started to be read to perform a critical analysis of the articles. For this, the following criteria were adopted: (1) the level of application of the model; (2) the software used for simulation; (3) the nature of the data used in the model, which may be real or estimated; (4) how waste is addressed, that is, whether it is considered by its typology or in an aggregated way; (5) the variables simulated in the proposed scenarios; (6) and, finally, if other methods were combined with DS. These subdivisions of the criteria were determined according to the literature (already applied or suggestions from the studies) according to Table 1.

Table 1. Criteria for the classification of publications.

\begin{tabular}{|c|c|c|c|c|c|}
\hline Application Level & Software & Data & Waste & Simulated Variables & Additional Methods \\
\hline Municipal & Vensim & Real & Aggregated & Generation & Multicriteria analysis \\
\hline State & Stella & Estimated & Dissociated & Collection & Soft Systems \\
\hline National & Powersim & Real and estimated & & Treatment & Multi-objective optimization \\
\hline Regional & iThink & & & Disposal & Delphi \\
\hline \multirow[t]{5}{*}{ Local } & DYNAMO & & & Technical factors & Fuzzy TOPSIS \\
\hline & Simile & & & Environmental factors & Fuzzy logic \\
\hline & & & & Sociocultural factors & Hierarchical Process Analysis \\
\hline & & & & Economy & Multiple Linear Regression \\
\hline & & & & Government & \\
\hline
\end{tabular}

In the scope of application, studies involving the city or its subdivisions, such as neighborhoods and regions, are considered municipal. The state level comprises studies covering more than one city, a specific region of the state or even the entire state. Similarly, at the federal scale, studies covering several states, regions of the country or the entire country are considered. The regional scale involves a set of countries. Finally, there are studies with applications in specific locations, such as universities or other locations that do not fall under the previous categories, so it was decided to classify them separately as 'Local'. Figure 2 shows the list of publications by application level, i.e., by the scope of the modeling proposed by the authors.

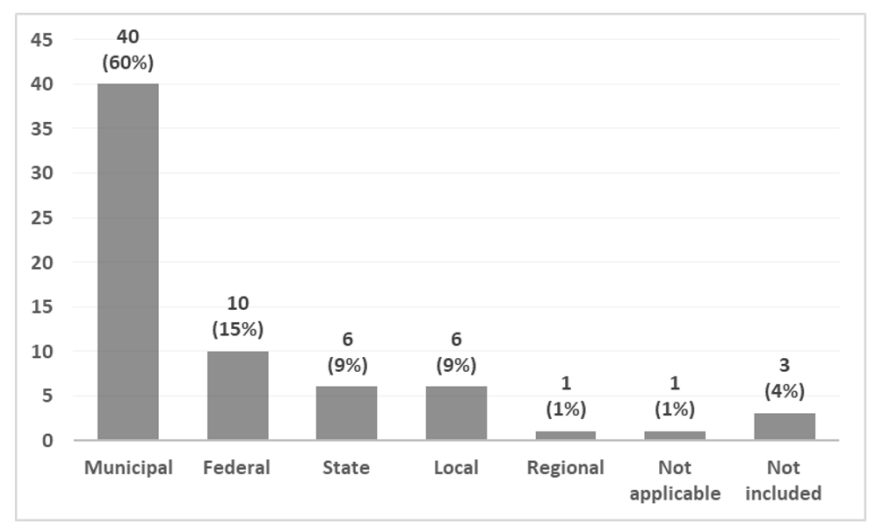

Figure 2. Modelling level of application. 
Considering the research design, it was possible to verify in which countries the studies on the modeling of USW management by the SD method are more concentrated. First, Brazil appears, with a total of 11 studies, followed by India (7), Thailand (6), China (5), Bangladesh (4) and the USA (3), even with the keywords used in the search were mostly in English. Brazil stood out ahead of India (2nd) and China (4th), countries belonging to the BRICS, in addition to other developed countries such as the USA (6th), Latvia, Singapore, Switzerland, and Spain (all four tied for 7th), Greece, Germany, Belgium, Estonia and Lithuania (8th). This is due to the search for Portuguese words in the Google Scholar database. In addition, among the 11 Brazilian articles, 8 belong to the same author indicating the concentration of papers. These articles deal with the same problem situation, in the same place of application. Therefore, the SD method still has little representation in the country, indicating the opportunity to represent and simulate USW management systems in other regions of Brazil.

There are several SD modeling software on the market, of which 7 were used by the studies analyzed: Vensim, which has a free version (Ventana Systems, 2018), Stella and iThink, belonging to the same platform (isee systems), Powersim, DYNAMO, and Simile. As for the provenance of the data, the studies analyzed used real, estimated data or both. In the first case, the data are obtained by government agencies, research institutes, associations, among others. In case this is not possible, or even if it is a hypothetical study, the data were estimated. The two types of data were combined when real data for simulated variables were not available.

Regarding the waste approach, it can be considered aggregated, that is, without distinction of each typology, or dissociated, showing each category of material that is being addressed. It allows the simulation of specific measures for each typology. As indicated in Table 1, the simulated variables presented were defined according to the literature review related to the factors that influence the solid waste management system. In this theoretical review, it was found that SD was often used together with other methods. The methods indicated in Table 1 were those found in the analyzed sample.

\section{Results and discussion}

Among the various software used for modeling USW management, in the study sample Vensim, Stella and Powersim software were the most used. Figure 3 shows the software used by the studies that compose the analyzed bibliographic portfolio.

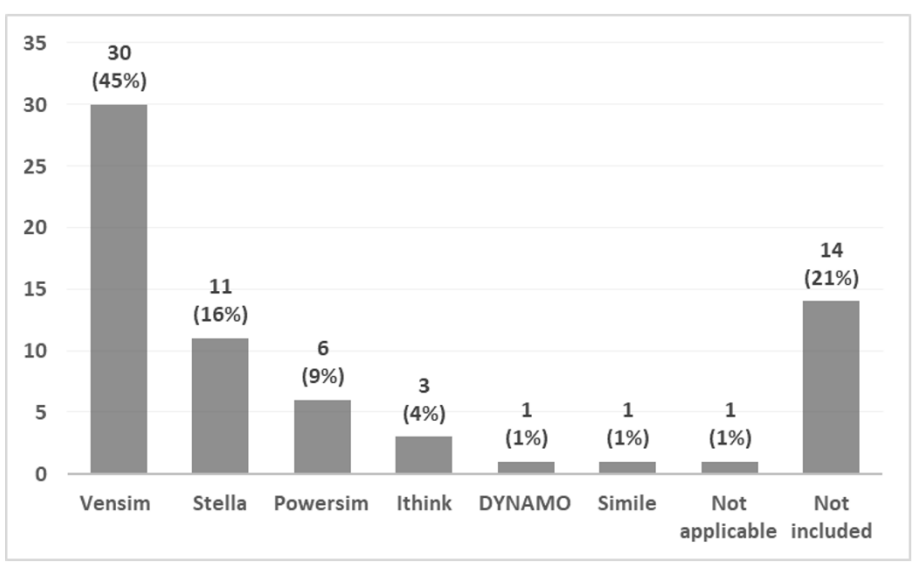

Figure 3. Softwares used in the papers analyzed. 
The predominance of studies that used the Vensim software for modeling and simulation can be explained by the existence of its free version for educational purposes, in addition to being easy to understand and apply. The software has a very strong position in the market, but also in the academic area (Bureš, 2015). Analyzing the distribution of software usage over the years, before 2002 there are no studies between the analyzed papers that used Vensim. This behavior can be explained by the fact that the free version, Vensim PLE (Personal Learning Edition), was launched in 1996, expanding access to this tool.

The second most used software was Stella. Its target audience is students, professors and researchers (Bureš, 2015). Stella was one of the first dynamic modeling systems to achieve widespread recognition and use, mainly due to its easy-to-use graphical interface (Costanza \& Voinov, 2001). Powersim is focused on risk simulation, analysis, management and optimization, which helps organizations to develop strategic plans and identify practical solutions (Bureš, 2015). The process of building the models, as well as defining the variables, is very similar to that of Stella (Santos, 2006). As the portfolio under analysis is composed of scientific research, and Powersim's focus is on business simulations, the position of third place among the others is justified.

IThink, being from the same manufacturer as Stella, has a very similar language, however, they are marketed to different audiences (Barlas, 2009). While Stella targets researchers, iThink targets business consumers (Bureš, 2015). DYNAMO was the first SD simulation language and explicitly displayed the equations used to assist apprentice SD users (Barlas, 2009). However, it does not have a graphical interface of the causal loop diagrams or the flow diagrams of the created model, which compromises its visualization. Besides, this software only has paid versions (Figliuolo et al., 2013), which may explain its small use in the analyzed papers. Simile, on the other hand, is a software aimed at developing models for analyzing environmental, ecological and biological systems, restricting the variety of problems that can be treated with this tool (Santos, 2006). Its specificity justifies its low use, although the subject of study is within its scope.

The data used in the modeling was predominantly ( $88 \%)$ real, followed by $6 \%$ estimated, and $3 \%$ combined. However, $3 \%$ of the papers did not inform the origin of the data used in the SD simulation. The four studies that used estimated data in their models indicated the lack of reliable or incomplete historical data available as obstacles. Other studies do not reflect the situation of a specific location. As it is a general model applicable to several realities, estimated data were used for testing (Pai et al., 2014; Rong, 2004).

The studies predominantly address waste in aggregate (41 papers). This fact was already expected due to the less complex models involving the USW without distinction of typologies. The other 26 papers address waste in a disaggregated manner, in which several specific types of waste are considered or focus on only one. There are also studies that, instead of classifying waste by its composition, categorize by recycling capacity or by its origin (industrial and domestic, for example).

\subsection{Proposed modeling}

Analyzing the models proposed in the bibliographic portfolio, the main variables addressed for each stage of USW management were identified, as well as the external factors that interfere in this process, as summarized in Table 2. 
Table 2. Main factors influencing USW management.

\begin{tabular}{cc}
$\begin{array}{c}\text { Generation } \\
\text { and sorting }\end{array}$ & Population (55), gravimetric composition of the waste (12), sorting on source (8) \\
\hline $\begin{array}{c}\text { Collection and } \\
\text { transport }\end{array}$ & Efficiency / Effectiveness of the transportation and collection service (9) \\
\hline Treatment & $\begin{array}{c}\text { Recycling (50), incineration (16), compost (17), anaerobic digestion (2), } \\
\text { production of waste fuel (3), generation of electricity / energy from USW (10), } \\
\text { informal recycling system (5), treatment efficiency (5), treatment energy (2) }\end{array}$ \\
\hline Disposal & Sanitary landfill (33), uncontrolled disposition (6), gas generation in landfills (6) \\
\hline
\end{tabular}

Note: the number of studies that considered the factors in their models is shown in parentheses.

There is a strong relationship between population variation and the generation of waste, this variable is used by $75 \%$ of the analyzed works, in addition to the highlight of recycling ( $70 \%$ of papers) as a waste treatment option, and the final destination of these in landfills (45\%). One of the factors that influence the management of USWs is the operational / technical elements, which involve the infrastructure for the system. Approximately $18 \%$ of the models proposed considered the presence of such a factor, classified in labor, collection vehicles and equipment and their effectiveness, and the availability of urban bins.

Guo et al. (2016) included in their modeling the variable "availability of street bins". The authors modeled the decision to dispose of domestic waste according to a weighted sum of descriptive and injunctive norms, financial incentives and availability of street bins. Given a high number of bins, inadequate waste disposal can be reduced. However, it is possible to generate an undesirable effect by stimulating chaotic dumping in large quantities, which, in turn, contributes to the population growth of rats in the municipality.

Regarding labor, 11 studies (Sufian \& Bala, 2007; Akinyemi, 2014; Rahayu et al., 2013; Bala et al., 2017; Bala, 2009; Kum et al., 2005; Manasakunkit \& Chinda, 2017; Manasakunkit \& Chinda, 2014; Manasakunkit, 2013; Matos, 2012; Sukholthaman \& Sharp, 2016) used the human strength necessary for the entire USW management process as variables, such as the wages of employees of collecting vehicles (collection) and waste sorting. The inclusion of such a variable allows for a more realistic analysis of the process since it is a factor that interferes on the costs of the system.

Collection vehicles and equipment are considered in some models ( $12 \%$ of the sample), which makes it possible to relate the collection capacity, the number of trips required, purchase price and fuel consumption, impacting the total collection costs (Sufian \& Bala, 2007; Akinyemi, 2014; Rahayu et al., 2013; Bala et al., 2017; Bala, 2009; Sukholthaman \& Sharp, 2016; Vélez \& Mora, 2016; Paucar \& Ataucusi, 2017). It is necessary to analyze, in a complementary way, the effectiveness of the labor, vehicles and collecting equipment, to simulate policies that interfere in the productivity of the process (Akinyemi, 2014).

\subsubsection{Environmental approach}

Some authors address the generation of environmental pollution from the noncollected, untreated and improperly disposed waste, which deteriorates the quality of health and the environment (Sufian \& Bala, 2007; Sufian \& Bala, 2006; Cai \& Liu, 2013; Rong, 2004; Guzmán, 1998; Kum et al., 2004). An example of this decrease in quality is presented by the model proposed by Pai et al. (2014), which relates pollution to population variation (births and deaths). However, the authors do not specify the source of such pollution. Besides them, Paucar \& Ataucusi (2017) modeled the contamination generated 
by the emission of gases and leachate from controlled landfills, which is an influential variable in the death rate.

Rodrigues et al. (2017) and Rizzetti et al. (2016) proposed a model for the use of cooking oil, from University Restaurants, as a raw material for the production of biodiesel, to be used as fuel for city collection trucks. The authors inserted a variable to calculate the potential reduction in water pollution due to incorrect disposal of the oil used, in addition to estimating the amount of $\mathrm{CO}_{2}$ gas emitted by the collection trucks (this value tends to decrease with the addition of biodiesel). Similarly, Ocoró \& Gúzman (2014) modeled the accumulation of $\mathrm{CO}_{2}$ in the atmosphere from waste incineration, consumption of virgin PET and disposal of solid waste in landfills. The authors concluded that the implementation of mechanisms for recycling waste can decrease the amount of $\mathrm{CO}_{2}$ emissions.

It is still possible to relate pollution to waste collection rates. Kum et al. (2004) modeled the population's willingness to pay for the collection service and concluded that, as the pollution rate increases, the number of citizens willing to pay the collection fee also increases. Other policies analyze the impact of environmental policies on waste generation, such as the ban on free plastic bags (Long et al., 2012), and the availability of the municipal budget for the management of USW (Ahmad, 2012; Alam \& Ahmad, 2015; Sufian \& Bala, 2006; Sufian \& Bala, 2007; Akinyemi, 2014; Rahayu et al., 2013; Bala et al., 2017; Bala, 2009; Rong, 2004; Sudhir et al., 1997; Zanjani et al., 2012; Sukholthaman \& Sharp, 2016; Kum et al., 2004).

\subsubsection{Economical approach}

As for economic aspects, many authors identified the proportional relationship between the amount of USW generated and the population and economic variation (GDP, average income per capita, or both), being modeled by 30 articles (Ahmad, 2012; Alam \& Ahmad, 2015; Sufian \& Bala, 2007; Sufian \& Bala, 2006; Akinyemi, 2014; Yeh et al., 2002; Chen et al., 2012; Giannis et al., 2016; Rahayu et al., 2013; Pubule et al., 2014; Vivekananda \& Nema, 2014; Bala et al., 2017; Bala, 2009; Rong, 2004; Guzmán, 1998; Estay-Ossandon \& Mena-Nieto, 2018; Estay-Ossandon et al., 2018; Inghels \& Dullaert, 2010; Sudhir et al., 1997; Kollikkathara et al., 2010; Zanjani et al., 2012; Dyson \& Chang, 2005). In addition to the two economic parameters mentioned, other factors can be used, as proposed by Dyson and Chang (2005), which suggest the income growth rate of the economic bloc (whose city of study belongs) as a factor of influence in the generation of waste.

Some studies combined different levels of income or population densities and assessed the impact of these changes on the generation of waste, as did Pai et al. (2014) when classifying the population into three income groups (low, medium and high) and simulating the generation of waste for each income level. Similarly, Chinda (2015) combined three income ranges (low, medium and high) with three population density scales (low, medium and high) when proposing a model for recycling household waste. The simulation concluded that middle and high-income households recycle more waste than low-income households. The study concluded that this fact can be explained by the difference in education and knowledge about recycling. This result is in line with the model developed by Rong (2004), which identified the relationship between GDP per capita and recyclable waste: as GDP increases, the amount of recyclable waste generated is greater.

Kollikkathara et al. (2010) used GDP to calculate the generation of waste according to the level of prosperity (very high, high, medium and low), which involves, in addition to GDP, the agricultural labor force, infant mortality rate, average family size, population 
between 15 to 59 years and life expectancy. More categorically, Chen et al. (2012) and Giannis et al. (2016) used the industrial GDP to relate to the generation of industrial waste. Yeh et al. (2002) also used the categorized GDP and classified the sources of waste as industrial, agricultural and services. Finally, Long et al. (2012) and Long et al. (2010) categorized the municipal plastic waste system into four sources of generation, with GDP influencing the generation of waste in public business places.

Other applications for GDP were addressed by Dace et al. (2014) and Massote et al. (2015) to estimate packaging consumption. After becoming a waste, the packaging impacts the value of the municipal budget, which in turn influences the financial resources available for the management of USW (Ahmad, 2012; Alam \& Ahmad, 2015; Sufian \& Bala, 2007; Sufian \& Bala, 2006; Rahayu et al., 2013; Bala et al., 2017; Bala, 2009; Rong, 2004). Other authors use green GDP, an indicator that refers to the difference between commonly used GDP and economic losses caused by factors such as environmental pollution and degeneration of natural resources to determine the relationship with the USW (Yeh et al., 2002; Cai \& Liu, 2013).

The models proposed in the analyzed articles still consider the revenue obtained from the sale of recyclable materials (Ahmad, 2012; Rahayu et al., 2013; Sudhir et al., 1997; Al-Khatib et al., 2015; Kum et al., 2005; Zanjani et al., 2012; Manasakunkit \& Chinda, 2017; Manasakunkit \& Chinda, 2014; Manasakunkit, 2013; Matos, 2012; Ribeiro, 2012), electricity generated from landfill gases (Ahmad, 2012), electricity generated from waste incineration (Rahayu et al., 2013), composting (Ahmad, 2012; Rahayu et al., 2013; Zanjani et al., 2012) and the disposal and facilities of waste treatment (Ahmad, 2012). So, in these papers, the revenue with different activities related to the USW management was also included in the SD model.

On the other hand, the USW management system is also influenced by the operational costs of the process, which includes the stages of collection, separation, treatment and disposal of waste. This cost variable is present in approximately $40 \%$ of the articles, demonstrating its relevance for analysis of policy implementation, more realistic estimates of the municipal budget necessary for the maintenance of the system and identification of process improvement (Ahmad, 2012; Alam \& Ahmad, 2015; Sufian \& Bala, 2007; Akinyemi, 2014; Yeh et al., 2002; Chen et al., 2012; Giannis et al., 2016; Rahayu et al., 2013; Cai \& Liu, 2013; Bala et al., 2017; Bala, 2009; Rong, 2004; Sudhir et al., 1997; Massote et al., 2015; Al-Khatib et al., 2015; Kum et al., 2005; Zanjani et al., 2012; Manasakunkit \& Chinda, 2017; Manasakunkit \& Chinda, 2014; Manasakunkit, 2013; Matos, 2012; Chinda, 2015; Karavezyris et al., 2002; Ulli-Beer et al., 2004a, b; Sukholthaman \& Sharp, 2016; Vélez \& Mora, 2016; Kum et al., 2004; Rodrigues et al., 2017).

The SD method also makes it possible to estimate the savings generated from the implementation of USW management system or to assess the cost-benefit of a given policy. Some authors have evaluated the electric energy savings provided by recycling each type of waste, that is, the difference in electric energy required for production from the raw material and using recycled material (Simonetto \& Löbler, 2013; Simonetto et al., 2013), which allows evaluating financially the gains obtained by recycling waste, according to Simonetto et al. (2014) and Rizzetti et al. (2016) modeled. These authors simulated the use of oil used in university restaurants for the production of biodiesel and identified savings of more than $R \$ 120,000.00$ in the acquisition of diesel over 10 years.

Manasakunkit \& Chinda (2017), Manasakunkit \& Chinda (2014) and Manasakunkit (2013) evaluated the decision to hire employees for the municipal recycling program based on the program's cost and benefit. Costs involve labor wages and transporting waste to recycling centers, while the benefits consist of savings in the costs of transporting 
waste to the landfill, in addition to the revenue obtained from the sale of recyclable materials. That way, if the benefits outweigh the costs, new employees would be hired. Similarly, Chinda (2015) used cost and benefit analysis to assess the implementation of a recycling program. To this end, transport costs and revenue from the sale of recyclable materials were considered.

It is also possible to relate the proportion of people employed in the USW management system. Dyson \& Chang (2005), for example, used the job growth rate to predict per capita income and population growth, which influences the USW in the city under study. Another option is the association between the proportion of people employed and the generation of waste in non-public places (Long et al., 2012; Long et al., 2010).

\subsubsection{Social approach}

Papers also address the formalization of the informal recycling sector. Ribeiro (2012) modeled a cooperative management system for recyclable material collectors, which is one of the alternatives for collectors to obtain better working conditions, social recognition and social inclusion. The model considers the financial inputs and outputs of the cooperative, including quotas for each member. Vélez \& Mora (2016) simulated the effect of formalizing the informal sector on the USW management system, to analyze how this process can solve social and environmental questions. Regarding the social, there was an improvement in income that could lead to better living conditions for the population. By the environmental sphere, it is possible to reduce the amount of waste to be collected and discarded, raw materials used in the production processes and, thus, the energy consumption during the manufacture of new products. The simulation also indicated an increase in tax collection by the municipality, a reduction in system costs and an improvement in the social problem. However, this approach was not involved in-depth in the papers that constitute the sample.

\subsubsection{Behavior approach}

Many authors simulate the environmental awareness of the community. Environmental pollution increases the annoyance and irritation of the population. Thus, the public concern develops to reduce the generation of waste and separate recyclable waste at the source (Sufian \& Bala, 2007; Sufian \& Bala, 2006; Bala et al., 2017; Bala, 2009; Sudhir et al., 1997). Guzmán (1998) highlights the situation in which this concern leads the population to pressure the government on the management of USW in the city.

The relationship between the population's environmental concern and the generation of waste is identified by many authors (Sufian \& Bala, 2007; Sufian \& Bala, 2006; Long et al., 2012; Bala et al., 2017; Bala, 2009; Long et al., 2010; Sudhir et al., 1997; Kollikkathara et al., 2010). As the population becomes aware of environmental impact and the importance of reducing waste production, the total waste generated decreases. Such awareness can be increased through advertising or political guidance, advocating the minimum use of plastic products (Long et al., 2012).

Many authors have modeled the impact that population's environmental behavior causes in waste recycling. Dace et al. (2014), for example, classified the population into four groups based on their motivations and habits: people who do not separate waste and are not willing to separate; people concerned about the environment and who would like to separate the waste but do not have access to the sorting facilities; people who perform the separation because they care about the environment; and people who perform the 
separation for economic reasons (or survival). It is assumed that the motivation for sorting is mainly driven by the environment (number of environmentalists in the vicinity) and the prevailing economic circumstances (waste management costs). Similarly, Zanjani et al. (2012) used a stock variable to quantify the population willing to separate their waste with public pressure (manifested from environmental pollution) and a municipal incentive plan as motivators.

Karavezyris et al. (2002) also simulated the environmental behavior of the population, relating to the habits of handling and separating waste in their homes. The increase in community awareness leads to a higher rate of waste recycling. Inghels \& Dullaert (2010) considered the selective collection behavior of the inhabitants as one of the influential factors in the generation of waste in the city. The authors indicated, as future work, the insertion of the tax policy related to waste disposal and to verify its impact on the separation behavior at the source to analyze the effect generated.

Ulli-Beer et al. (2004a, b) analyzed the influence of human behavior and public policies on the decision to separate waste or not. The authors classified the population into two main groups (willing to separate and unwilling), subdivided into two more subgroups that represent citizens in transition, combining experience with the willingness to separate. This transition between groups is attributed by the authors to the perceived social norms of separation. The habits of the community influence the decision, as well as the costs involved in the incineration of the waste, since an increase in such costs can lead to a reduction in the quality of the separated waste (from the mixture of recyclable and incinerable materials). As for public policies, a tax on waste was simulated to promote the separation of waste in the municipality, in addition to prepaid disposal fees to alleviate public accounts. The authors concluded that the implementation of this prepaid rate demonstrated an effective incentive for waste separation.

Sukholthaman \& Sharp (2016) addressed the factors that affect human attitudes in waste separation in their model. The change in the attitude of separation was calculated from different levels of incentives or knowledge provided about USW management. In addition to the waste separation behavior, some authors analyzed the decision to reduce generation, waste disposal, and packaging reuse. To analyze this behavior, Guo et al. (2016) took into account the influence of social, injunctive and descriptive norms. Descriptive norms refer to what most people do, while injunctions focus on what the majority approves or disapproves. Regarding the option of reusing waste, Babader et al. (2016) developed a model that identifies the influence of social norms (of friends and family) and the effect of practitioners of packaging reuse, in the awareness of uninformed people about packaging reuse. The model also assesses people's behavioral adaptation to become practitioners of packaging reuse through the best product packaging conditions and the perceived convenience in reusing it.

Lilley (1997) drew an average profile of the inhabitants determined by seven sociodemographic variables: age, political ideology, income, environmental knowledge, level of education, gender and house location. In its model, the behavior is influenced by the community's intention to adopt such behavior, resulting from the weighted sum of the attitude and subjective norms, external laws for the prevention of solid waste, incentives (for example, financial), besides the barriers for such behavior, such as the absence of a recyclable collection system in the community. Another factor considered is the behavioral belief, resulting from the perception of efforts to reduce the generation of waste and the training offered on the proper procedure, such as programs to help on which materials are recyclable and the frequency of collection (Guo et al., 2016).

In addition to this study, Kollikkathara et al. (2010) analyzed the effects of public and internal waste prevention measures in Newark (USA). Such measures are the promotion 
of repair services, reusable goods and rental services; intensified municipal public relations; home composting; reusable material; use on both sides of paper. The authors realized that there is an increasing tendency to increase the fraction of waste not collected each year. As a result, the cost of waste treatment and disposal in landfills increases, making recycling the preferred option for non-collected waste. Kollikkathara et al. (2010) recommend the creation of new policy measures that reduce the cost of recycling to increase the efficiency of operations and the markets for recyclable materials.

Other factors considered were educational level, modeled by Estay-Ossandon et al. (2018), and the relationship between genders (female and male) proposed by Chinda (2015). According to the authors' research, the proportion of waste recycled by men and women is different. Therefore, they suggest including gender analysis in research on recycling and the simulation of different policies specific to each group.

Some studies also simulate population resistance. In the first case, Rong (2004) considers the community's opposition to the installation of a landfill. The proposed way to overcome resistance was to offer compensation to the population, which leads to an increase in the investment cost of the facility (waste disposal costs). The second example refers to the model developed by Adamides et al. (2009), whose problem involves public resistance to new waste processing technologies that delay the development of waste treatment capacity. This variable is influenced by the flow of waste disposed in an unmonitored manner for properly treated (landfill and new technologies), as well as by the degree of technical awareness and participation in public decision-making. With CATWOE (Customers, Actors, Transformation, World View, Owner e Environment constraints), the authors proposed a system to promote public awareness that, with the help of the population, plans and implements actions to increase public awareness of the methods and technologies available for waste management and its effects on the environment and humans.

\subsubsection{Regulation approach}

Approximately $34 \%$ of the articles consider the influence of policies and regulations on their models, which includes incentives, laws, taxes, programs, among others. As for the programs, Zanjani et al. (2012) proposed a municipal incentive plan to motivate the population to separate waste. This plan could involve discounts on city commerce or tax cuts, so that citizens' enthusiasm for separation would increase recycling efficiency. In addition, the authors consider the presence of a tax on the generation of waste in the population; however, this variable is not discussed throughout the article. Another municipal incentive was included in the model proposed by Chinda (2015). It simulated government support in activities related to recycling, such as the provision of recycling bins and the promotion of recycling programs through various media channels; so that, as the population acquires knowledge, the amount of waste recycled increases.

It is also possible to promote a financial incentive for the population, as proposed by Guo et al. (2016). The authors simulated the presence of such incentives to reduce incorrect waste disposal and encourage recycling. Among the simulated interventions, the combination of improved social norms and financial incentives resulted in better promotion of appropriate behaviors related to waste. Seeking a stricter control, certain authors addressed the presence of laws and regulations on the management of USW, such as the model proposed by Pubule et al. (2014), which includes a governmental directive on minimizing the destination of organic waste to landfills. 
Regarding recycling, Kum et al. (2005) identified the dependency relationship between waste separation and the population that is motivated (in many cases) by the recyclables price. As recycling is not dependent on this factor, the authors simulated the insertion of a regulation on the separation of waste by the inhabitants. Similarly, Sukholthaman \& Sharp (2016) also simulated the insertion of regulations in which the separation of waste (recyclable and organic) by citizens is mandatory. The results show a decrease in the amount of waste destined for landfills, which leads to a reduction in transport costs and thus provides savings to municipal funds. Given the large volume of waste disposed of illegally, it becomes relevant to model a regulatory variable regarding the illegal disposal of waste, as proposed by Karavezyris et al. (2002). This measure was simulated according to the strictness or relaxation of the regulation, resulting in lower proportions of residues illegally disposed, for the first case.

Massote et al. (2015) discussed the limitations and perspectives of the implementation of the reverse logistics model in companies aiming at complying with the National Solid Waste Policy in Brazil. The authors concluded that the policy is not a powerful tool for changing investments in research and product development, while increasingly complex packaging is expected to reduce recycling efficiency. Therefore, a fiscal incentive must be integrated into the policy in order to encourage companies to invest in eco-innovation.

When regulations are included in the model, it is important to consider the pressure from the private sector. Guzmán (1998) portrays in his model the existence of the private sector, together with the public, in the management of USW. The author indicates the pressure exerted by this sector to collect and dispose the urban waste. As such, the total pressure exerted under the government is composed of public pressure and the private sector.

\section{Final considerations}

With the increase in environmental concern, the number of studies on the management of urban solid waste has increased. The use of the system dynamics method for representing and simulating such a system has emerged as a viable strategy to deal with the complexity involved. Among the analyzed bibliographic portfolio, the first study was published in 1993 in the United States. Only 10 years later, research using this method was found in Brazil, demonstrating the delay between access / knowledge of new methodologies in the country. Although Brazilian articles stood out in quantity, as a characteristic of the intention to verify studies at the national level, the articles are restricted to a few authors, demonstrating the limited use of the method.

Among the variables addressed in the models, the influence of population size on waste generation was evident, in addition to the effectiveness of using treatment methods and correct options for final disposal. Economic and behavioral factors have been privileged in the analyzed models. Despite this, new variables can be inserted in the models such as consumption habits of the population, level of education, seasonal population, market prices of goods made from recycled waste, society's effort to separate waste between the various population groups (human behavior).

Therefore, it is possible to notice gaps when analyzing the literature related to the absence of factors about collection, such as route planning; environment, such as the control and assessment of environmental impacts; finance, such as private sector participation in management systems; and the institutional scope, such as the knowledge of municipal administrators about waste, prioritizing waste problems and the effectiveness of municipal management. As study opportunities pointed out by the analyzed studies, the 
disaggregated waste approach stands out, to insert treatment and destination options geared to each type of material. Another suggestion refers to private investment to provide another source of financing for structuring the logistics and waste management network, interventions that focus on reducing waste at the source, and incorporating delays between the stages of production - consumption - waste for consumers major USW groups.

\section{Acknowledgments}

This research was funded by the National Council for Scientific and Technological Development - CNPq (Process 308411/2018-8 and scientific initiation scholarship). The data used in the research are deposited in the Mendeley Data repository (https://data.mendeley.com/datasets/cpr8bttgz3/1 DOI: 10.17632/cpr8bttgz3.1).

\section{REFERENCES}

Abeliotis, K., Karaiskou, K., Togia, A., \& Lasaridi, K. (2009). Decision support systems in solid waste management: a case study at the national and local level in Greece. Global NEST Journal, 11(2), 117-126.

ABRELPE (2018). Panorama dos resíduos sólidos no Brasil 2018/2019. Recuperado em 24 de março de 2020, de http://abrelpe.org.br/download-panorama-2018-2019/

Adamides, E. D., Mitropoulos, P., Giannikos, I., \& Mitropoulos, I. (2009). A multi-methodological approach to the development of a regional solid waste management system. The Journal of the Operational Research Society, 60(6), 758-770. http://dx.doi.org/10.1057/palgrave.jors.2602592.

Ahmad, K. (2012). A system dynamics modeling of municipal solid waste management systems in Delhi. International Journal of Research in Engineering and Technology, 1(4), 628-641. http://dx.doi.org/10.15623/ijret.2012.0104014.

Akinyemi, O. O. (2014). System dynamics modelling of waste management system. In Proceedings of the 2014 Asia-Pacific System Dynamics Conference (pp. 1-14). Tokyo, Japan: Chapter of the System Dynamics Society.

Alam, S., \& Ahmad, K. (2015). Modeling of municipal solid waste management system using powersim studio-A Case Study. Journal of Energy Research and Environmental Technology, 2(2), 117-122.

Al-Khatib, I. A., Eleyan, D., \& Garfield, J. (2015). A system dynamics model to predict municipal waste generation and management costs in developing areas. Journal of Solid Waste Technology Management, 41(2), 109-120. http://dx.doi.org/10.5276/JSWTM.2015.109.

Babader, A., Ren, J., Jones, K. O., \& Wang, J. (2016). A system dynamics approach for enhancing social behaviours regarding the reuse of packaging. Expert Systems with Applications, 46, 417-425. http://dx.doi.org/10.1016/j.eswa.2015.10.025.

Bala, B. K. (2009). Modeling of Solid Waste Management Systems. In Proceedings of 1st International Conference on Energy, Environment, and Sustainable Development for Growing Economies. Jamshoro: Mehran UET.

Bala, B. K., Arshad, F. M., \& Noh, K. M. (2017). System dynamics: Modelling and simulation. Singapore: Springer. http://dx.doi.org/10.1007/978-981-10-2045-2.

Barlas, Y. (2009). System dynamics. Singapore: Eolss Publishers.

Brasil. (2010). Lei $n^{\circ}$ 12.305, de 2 de agosto de 2010. Institui a Política Nacional de Resíduos Sólidos, altera a Lei $n^{\circ}$ 9.605, de 12 de fevereiro de 1998 e dá outras providências. Brasília, DF: Diário Oficial da República Federativa do Brasil. 
Bureš, V. (2015). Comparative analysis of system dynamics software packages. International Review on Modelling and Simulations, 8(2), 245-255. http://dx.doi.org/10.15866/iremos.v8i2.5401.

Cai, L., \& Liu, Y. (2013). Application of system dynamics for municipal waste management in china: a case study of Beijing. In Conference Proceedings of the 31st International Conference of the System Dynamics Society. Massachusetts: SSD.

Chen, M., Giannis, A., \& Wang, J.-Y. (2012). Application of system dynamics model for municipal solid waste generation and landfill capacity evaluation in Singapore. The Macrotheme Review, $1(1), 101-114$.

Chinda, T. (2015). The Development of a Dynamic Model of Household Waste Recycling in Bangkok, Thailand. In Proceedings of the 6th International Conference on Engineering, Project, and Production Management. Gold Cost: Griffith University. http://dx.doi.org/10.32738/CEPPM.201509.0050.

Clarivate. (2018). Web of Science. Recuperado em 01 de outubro de 2018, de http://wokinfo.com/?utm_source=false\&utm_medium=false\&utm_campaign=false\&utm_source =false\&utm_medium=false\&utm_campaign=false

Costanza, R., \& Voinov, A. (2001). Modeling ecological and economic systems with STELLA: part III. Ecological Modelling, 143(1-2), 1-7. http://dx.doi.org/10.1016/S0304-3800(01)00358-1.

Dace, E., Bazbauers, G., Berzina, A., \& Davidsen, P. I. (2014). System dynamics model for analyzing effects of eco-design policy on packaging waste management system. Resources, Conservation and Recycling, 87, 175-190. http://dx.doi.org/10.1016/j.resconrec.2014.04.004.

Dyson, B., \& Chang, N. B. (2005). Forecasting municipal solid waste generation in a fast-growing urban region with system dynamics modeling. Waste Management, 25(7), 669-679. http://dx.doi.org/10.1016/j.wasman.2004.10.005.

Estay-Ossandon, C., \& Mena-Nieto, A. (2018). Modelling the driving forces of the municipal solid waste generation in touristic islands. A case study of the Balearic Islands (2000-2030). Waste Management, 75, 70-81. http://dx.doi.org/10.1016/j.wasman.2017.12.029. PMid:29454815.

Estay-Ossandon, C., Mena-Nieto, A., \& Harsch, N. (2018). Using a fuzzy TOPSIS-based scenario analysis to improve municipal solid waste planning and forecasting: a case study of Canary archipelago (1999-2030). Journal of Cleaner Production, 176, 1198-1212. http://dx.doi.org/10.1016/j.jclepro.2017.10.324.

Figliuolo, V., No., Oliveira, M. I., \& Maciel, J. S. C. (2013). Feasibility study for establishment of a new urban corridor in the region of the Igarapé da Lavanderia through dynamic systems. Journal of Transport Literature, 7(3), 137-176. http://dx.doi.org/10.1590/S223810312013000300007.

Giannis, A., Chen, M., Yin, K., Tong, H., \& Veksha, A. (2016). Application of system dynamics modeling for evaluation of different recycling scenarios in Singapore. Journal of Material Cycles and Waste Management, 19(3), 1177-1185. http://dx.doi.org/10.1007/s10163-0160503-2.

Google (2018). About Google Scholar. Recuperado em 23 de julho de 2018, de https://scholar.google.com.br/intl/pt-BR/scholar/about.html

Guerrero, L. A., Maas, G., \& Hogland, W. (2013). Solid waste management challenges for cities in developing countries. Waste Management, 33(1), 220-232. http://dx.doi.org/10.1016/j.wasman.2012.09.008.

Guo, H., Hobbs, B. F., Lasater, M. E., Parker, C. L., \& Winch, P. J. (2016). System dynamicsbased evaluation of interventions to promote appropriate waste disposal behaviors in lowincome urban areas: A Baltimore case study. Waste Management (New York, N.Y.), 56, 547560. http://dx.doi.org/10.1016/j.wasman.2016.05.019. PMid:27260985.

Guzmán, A. T. (1998). Urban Municipal Solid Waste Management in Costa Rica (Master of Science thesis). Massachusetts Institute of Technology, Cambridge. 
Healthy London (2018). Introduction to System Dynamics workforce modelling. Recuperado em 23 de abril de 2018, de https://www.healthylondon.org/wp-content/uploads/2017/11//Introductionto-System-Dynamics-workforce-modelling.pdf.

Inghels, D., \& Dullaert, W. (2010). An analysis of household waste management policy using system dynamics modelling. Waste Management \& Research, 29(4), 351-370. http://dx.doi.org/10.1177/0734242X10373800. PMid:20584878.

Karavezyris, V., Timpe, K. P., \& Marzi, R. (2002). Application of system dynamics and fuzzy logic to forecasting of municipal solid waste. Mathematics and Computers in Simulation, 60(3-5), 149-158. http://dx.doi.org/10.1016/S0378-4754(02)00010-1.

Kollikkathara, N., Feng, H., \& Yu, D. (2010). A system dynamic modeling approach for evaluating municipal solid waste generation, landfill capacity and related cost management issues. Waste Management, 30(11), 2194-2203. http://dx.doi.org/10.1016/j.wasman.2010.05.012. PMid:20547450.

Kum, V., Sharp, A., \& Harnpornchai, N. (2004). A system dynamic approach for financial planning in solid waste management: a case study in Phnom Penh city. Thammasat International Journal of Science \& Technology, 9(2), 27-34.

Kum, V., Sharp, A., \& Harnpornchai, N. (2005). A system dynamics study of solid waste recovery policies in Phnom Penh City. In Proceedings of the 23rd International Conference of the System Dynamics Society. Boston: SDS.

Lilley, L. E. (1997). A System Dynamics Investigation of Environmental Attitudes and Behaviors Influencing Solid Waste Reduction (Master of science thesis). Air Force Institute of Technology, Ohio.

Long, F., Song, B., Wang, Q., Xia, X., \& Xue, L. (2012). Scenarios simulation on municipal plastic waste generation of different functional areas of Beijing. Journal of Material Cycles and Waste Management, 14(3), 250-258. http://dx.doi.org/10.1007/s10163-012-0066-9.

Long, F., Song, B., Xia, X. F., Xue, L. L., \& Wang, Q. H. (2010). Study on the prediction model of the proportion of each type of urban domestic plastic waste. Advanced Materials Research, 113-116, 1383-1388. http://dx.doi.org/10.4028/www.scientific.net/AMR.113-116.1383.

Manasakunkit, C. (2013). A System Dynamics Approach to Municipal Solid Waste in Bangkok (Master of science thesis). Sirindhorn International Institute of Technology, Thammasat University, Pathum Thani.

Manasakunkit, C., \& Chinda, T. (2014). The validation of municipal solid waste dynamic model in Bangkok. International Journal of Advances in Agricultural and Environmental Engineering, 1(1), 121-126.

Manasakunkit, C., \& Chinda, T. (2017). Development of a municipal solid waste dynamic model in Bangkok, Thailand. Songklanakarin Journal of Science and Technology, 39(5), 685-695.

Massote, B., Demajorovic, J., \& de Moraes, E. A. (2015). Extended Producer Responsability Model: An Analysis on the Brazilian Case based on System Dynamics Approach. In Proceedings of the 33rd International Conference of the System Dynamics Society. Boston.

Matos, D. A. (2012). Tomada de decisão em redes logísticas de reciclagem de materiais através da Dinâmica de Sistemas (Tese de doutorado). Universidade de São Paulo, São Carlos.

Motta, G. D. S., \& Quintella, R. H. (2012). Assessment of non-financial criteria in the selection of investment projects for seed capital funding: the contribution of scientometrics and patentometrics. Journal of Technology Management \& Innovation, 7(3), 172-193. http://dx.doi.org/10.4067/S0718-27242012000300015.

Ocoró, M. F. V., \& Gúzman, L. E. C. (2014). Estudio dinámico del impacto ambiental asociado al reciclaje y reutilización de envases pet en el Valle Del Cauca (Trabajo de Grado). Universidad Del Valle, Santiago de Cali.

Ojoawo, S. O., Agbede, O. A., \& Sangodoyin, A. Y. (2012). System Dynamics Modeling of Dumpsite Leachate Control in Ogbomosoland, Nigeria. Journal of Environmental Protection, 3(1), 120-128. http://dx.doi.org/10.4236/jep.2012.31015. 
Pai, R., Rodrigues, L. L., Mathew, A. O., \& Hebbar, S. (2014). Impact of urbanization on municipal solid waste management: a system dynamics approach. International Journal of Renew Energy Environ Eng, 2, 2348-0157.

Paucar, F. A. C., \& Ataucusi, E. L. L. (2017). Modelo prospectivo para el manejo de los residuos sólidos del distrito de Pampas de la provincia de Tayacaja (Tesis de graduación). Universidad Nacional De Huancavelica, Huancavelica.

Pisani, R. Jr., Castro, M. C. A. A., \& Costa, A. Á. (2018). Desenvolvimento de correlação para estimativa da taxa de geração per capita de resíduos sólidos urbanos no estado de São Paulo: influências da população, renda per capita e consumo de energia elétrica. Engenharia Sanitaria e Ambiental, 23(2), 415-424. http://dx.doi.org/10.1590/s1413-41522018167380.

Popli, K., Sudibya, G. L., \& Kim, S. (2017). A Review of Solid Waste Management using System Dynamics Modeling. Journal of Environmental Sciences (China), 26(10), 1185-1200. http://dx.doi.org/10.5322/JESI.2017.26.10.1185.

Pruyt, E. (2013). Small system dynamics models for big issues: Triple jump towards real-world complexity (1a ed.). Delft: TU Delft Library.

Pubule, J., Blumberga, A., Romagnoli, F., \& Blumberga, D. (2014). Finding an optimal solution for biowaste management in Baltic States. Journal of Cleaner Production, 88, 214-223. http://dx.doi.org/10.1016/j.jclepro.2014.04.053.

Rahayu, N., Arai, T., Yudoko, G., \& Morimoto, H. (2013). System dynamics models for planning long-term integrated municipal solid waste management in Bandung city. The Sustainable City, 179, 2, 1153-1168. http://dx.doi.org/10.2495/SC130982.

Ribeiro, R. R. (2012). Avaliação de alternativas sócio-econômicas para a população em torno de aterros sanitários. Estudo de caso: Aterro de Gramacho (Dissertação de mestrado). Universidade Federal do Rio de Janeiro, Rio de Janeiro.

Rizzetti, T. A., Rizzetti, T. A., Rodrigues, G. O., Rodrigues, G. O., Simonetto, E. O., \& Gil, R. C. (2016). Uso de dinâmica de sistemas para avaliação de cenários de reaproveitamento de óleo de cozinha na produção de biodiesel em uma IES pública. Sistemas \& Gestão, 11(1), 112119. http://dx.doi.org/10.20985/1980-5160.2016.v11n1.1010.

Rodrigues, G. O., Schneider, J. R., Pereira, A., Simonetto, E. O., Lobler, M., \& Trevisan, M. (2017). Proposta de utilização do biodiesel em tratores de uma instituição de ensino superior: uma simulação computacional. Estudos do CEPE, 45(45), 74-91. http://dx.doi.org/10.17058/cepe.v0i45.8248.

Rong, L. (2004). Using system dynamics in decision support for sustainable waste management (Master of engineering thesis). National University of Singapore, Singapore.

Rosa, D. S., \& Andrade, J. S. (2016). Gestão de resíduos sólidos no Estado do Espírito Santo à luz da Política Nacional de Resíduos Sólidos. Revista Científica Intelletto, 1(1), 76-88.

Santos, A. M. (2006). A aplicação de um modelo de simulação para o gerenciamento de projetos: um estudo de caso utilizando a dinâmica de sistemas (Dissertação de mestrado). Universidade de São Paulo, São Paulo.

Satori, M., Megantara, E. N., Primiana, I. F., \& Gunawan, B. (2018). Review of the influencing factors of integrated waste management. International Journal of GEOMATE, 15(48), 34-40. http://dx.doi.org/10.21660/2018.48.55459.

Simonetto, E. D. O., Rodrigues, G. O., Dalmolin, L. C., \& Modro, N. R. (2014). O uso da dinâmica de sistemas para avaliação de cenários da reciclagem de resíduos sólidos urbanos. Revista Gestão, Inovação e Tecnologias, 4(2), 910-924.

Simonetto, E. O., \& Löbler, M. L. (2013). Simulação computacional para avaliação de cenários sobre a reciclagem de resíduos sólidos urbanos e o seu impacto na economia de energia. In Anais do IX Simpósio Brasileiro de Sistemas de Informação. João Pessoa: SBC.

Simonetto, E. O., \& Löbler, M. L. (2014). Simulação baseada em system dynamics para avaliação de cenários sobre geração e disposição de resíduos sólidos urbanos. Production, 24(1), 212224. http://dx.doi.org/10.1590/S0103-65132013005000034. 
Simonetto, E. O., Modro, N. R., \& Dalmolin, L. C. (2013). Assessment of energy saving in waste recycling using system dynamics. Revista de Administração da Universidade Federal de Santa Maria, 6(2), 319-332. http://dx.doi.org/10.5902/198346597166.

Sudhir, V., Srinivasan, G., \& Muraleedharan, V. R. (1997). Planning for sustainable solid waste management in urban India. System Dynamics Review. The Journal of the System Dynamics Society, 13(3), 223-246. http://dx.doi.org/10.1002/(SICI)1099-1727(199723)13:3<223::AIDSDR127>3.0.CO;2-Q.

Sufian, M. A., \& Bala, B. K. (2006). Modelling of electrical energy recovery from urban solid waste system: the case of Dhaka city. Renewable Energy, 31(10), 1573-1580. http://dx.doi.org/10.1016/j.renene.2005.07.012.

Sufian, M. A., \& Bala, B. K. (2007). Modeling of urban solid waste management system: the case of Dhaka city. Waste Management, 27(7), 858-868. http://dx.doi.org/10.1016/j.wasman.2006.04.011. PMid:16781136.

Sukholthaman, P., \& Sharp, A. (2016). A system dynamics model to evaluate effects of source separation of municipal solid waste management: A case of Bangkok, Thailand. Waste Management (New York, N.Y.), 52, 50-61. http://dx.doi.org/10.1016/j.wasman.2016.03.026. PMid:27026497.

System Dynamics Society (2018). What is SD. Recuperado em 23 de abril de 2018, de https://www.systemdynamics.org/what-is-sd.

Ulli-Beer, S., Andersen, D. F., \& Richardson, G. P. (2004b). Using a SD-SWM-model to inform policy making for solid waste management at the local level. In Proceedings of the 22 International Conference of the System Dynamics Society. Oxford: SDS.

Ulli-Beer, S., Richardson, G. P., \& Andersen, D. F. (2004a). A SD-choice structure for policy compliance: micro behavior explaining aggregated recycling dynamics. In Proceedings of the 22nd International Conference of the System Dynamics Society. Oxford: SDS.

Vélez, S. L. P., \& Mora, N. E. (2016). System dynamics model for the municipal solid waste management system in the metropolitan area of Medellín, Colombia. International Journal of Environment and Waste Management, 18(2), 161-180. http://dx.doi.org/10.1504/IJEWM.2016.080404.

Ventana Systems (2018). Vensim Software. Recuperado em 23 de setembro de 2018, de http://vensim.com/vensim-software/.

Vivekananda, B., \& Nema, A. K. (2014). Forecasting of solid waste quantity and composition: a multilinear regression and system dynamics approach. International Journal of Environment and Waste Management, 13(2), 179-198. http://dx.doi.org/10.1504/IJEWM.2014.059618.

Wilson, D. C., Rodic, L., Scheinberg, A., Velis, C. A., \& Alabaster, G. (2012). Comparative analysis of solid waste management in 20 cities. Waste Management \& Research, 30(3), 237-254. http://dx.doi.org/10.1177/0734242X12437569. PMid:22407700.

Yeh, S. C., Chu, Y. P., \& Yu, H. C. (2002). Dynamic economic-environmental simulation of waste pollution in Taiwan. Development and Application of Computer Techniques to Environmental Studies, 51, 289-298.

Zanjani, A. J., Saeedi, M., Kiani, B., \& Vosoogh, A. (2012). The effect of the waste separation policy in municipal solid waste management using the system dynamic approach. International Journal of Environmental Health Engineering, 1(1), 24-29. http://dx.doi.org/10.4103/22779183.94389. 